\title{
IMPLEMENTASI KEBIJAKAN ADAPTASI KEBIASAAN BARU DI MASA PANDEMI COVID-19 \\ (Studi Pada Masyarakat Pelaku UMKM di Sekitar Lingkungan Kampus IAI Darussalam Kelurahan Tanjung Rema Martapura)
}

\author{
Dairobi $^{1}$, Lola Malihah ${ }^{2}$, M. Yulian Ma'mun ${ }^{3}$, Bahriah $^{4}$ \\ ${ }^{1-4}$ Program Studi Perbankan Syariah, Fakultas Ekonomi dan Bisnis Islam \\ Institut Agama Islam Darussalam Martapura \\ 1. \\ ㅁahriahonly@email.com
}

\begin{abstract}
The Indonesian government policies in implementing "adaptation of new habits" during the Covid-19 pandemic are received various responses from the public. Some people are very supportive of the implementation because they are aware of the benefits and know the dangers of Covid-19. Furthermore, the others are still ignorant and do not respond well to the government's policy for various reasons. Among them are the economic reason and a lack of understanding of the Covid-19 risks and their implications for human health. The government also begin vaccination across the country to prevent the spread of the virus. This study uses a quantitative-descriptive method. It aims to determine the implementation of the "adaptation of new habits" in the community of the MSME businesspeople around the Darussalam Islamic Institute Martapura campus during the Covid-19 pandemic period. This study concludes that most of them obeyed the new Covid-19 health policies implemented by the government because most of them understand the dangers of Covid-19 transmission.
\end{abstract}

Keywords : Adaptation of new habits policy, Covid-19

\begin{abstract}
ABSTRAK
Impelemntasi kebijakan pemerintah dalam menerapkan adaptasi kebiasaan baru di masa pandemi Covid-19 mendapat berbagai macam respon dari masyarakat. Sebagian masyarakat ada yang sangat mendukung kebijakan tersebut dikarenakan memang sadar akan manfaatnya dan mengetahui bahaya dari Covid-19 itu sendiri, namun sebagaian masyarakat masih ada yang abai, tidak merespon dengan baik kebijakan pemerintah tersebut dikarenakan berbagai alasan, diantaranya karena alasan ekonomi atau kurangnya pemahaman akan bahaya yang ditimbulkan Covid-19. Pemerintah juga berupaya melakukan vaksinasi untuk menghambat penularan virus ini. Penelitian ini menggunakan metode kuantitatif-deskriptif. Penelitian bertujuan untuk mengetahui implementasi adaptasi kebiasaan baru pada responden yaitu para pelaku UMKM yang ada di sekitar kampus IAI Darussalam Martapura. Hasil penelitian ini menyimpulkan bahwa sebagian pelaku UMKM disekitar lingkungan kampus IAI Darussalam Martapura masuk dalam kategori mematuhi kebijakan adaptasi kebiasaan baru yang diterapkan oleh pemerintah. Hal ini dikarenakan sebagian besar dari mereka mengaku memang memahami akan bahaya dari penularan Covid-19.
\end{abstract}

Kata Kunci: Kebijakan adaptasi kebiasaan baru, pandemi Covid-19.

\section{PENDAHULUAN}

Covid-19 merupakan penyakit yang disebabkan oleh Novel Corona virus (2019nCoV) jenis virus baru yang pertama kali di temukan di Wuhan, Republik Rakyat Tiongkok. Virus ini menyebabkan penyakit mulai dari flu biasa sampai penyakit yang serius seperti Middle East Respiratory Syndrom (MERS) dan Sindrom Pernapasan Akut Berat/ Severe Acute Respiratory
Syndrom (SARS).Masa inkubasi virus ini rata-rata selama 5-6 hari dengan masa inkubasi terlama sepanjang 14 hari. Pada kasus COVID-19 yang berat dapat menyebabkan pneumonia, sindrom pernapasan akut, gagal ginjal, dan bahkan kematian(Kemenkes RI, 2020).

Organisasi Kesehatan Dunia (WHO) mengumumkan pada tanggal 11 Februari 2020 nama penyakit yang ditimbulkan oleh 
virus tersebut adalah Coronavirus Disease (Covid-19) dengan gejala umum seperti demam lebih dari $38^{\circ} \mathrm{C}$, batuk, dan napas yang sesak.Penularannya juga sangat cepat melalui tetesan kecil (droplet) yang keluar dari mulut atau hidung pada saat bersin atau batuk. Jika droplet tersebut jatuh pada benda, kemudian benda tersebut disentuh oleh orang lain, yang kemudian orang tersebut menyentuh daerah segi tiga wajah yaitu mata, hidung dan mulut, maka orang tersebut dapat terinfeksi Covid-19. Bahkan jika terhirup droplet melalui udara pun dapat menjadi penyebab penularan virus tersebut. Inilah sebabnya semua orang perlu menjaga jarak dan memakai masker(WHO, 2020).Virus Covid-19menyebar dengan cepat hampir ke seluruh negara di dunia, tidak terkecuali Indonesia. Di bulan Februari 2020 sudah ada warga negara Indonesia yang terkonfirmasi positif terpapar virus Covid-19. Virus ini menyebar dengan sangat cepat, dikarenakan memang proses penularannya yang begitu mudah dan pemahaman masyarakat yang masih kurang tentang penyakit tersebut.

Virus Covid-19 telah menyebar dengan cepat di seluruh negara didunia, juga menyebar dengan cepat diseluruh provinsi di Indonesia. Data dari Satuan Tugas Penanganan Covid-19 Republik Indonesia per Mei 2021, tercatat ada 1.791.221 kasus positif dengan 49.771 jiwa meninggal dunia di tanah air(Satgas Penanganan Covid-19 Nasional RI, 2021).

Beberapa wilayah di Indonesia masuk kategori zona merah dan hitam karena penyebaran yang begitu cepat. Di Kalimantan Selatan hampir setiap Kabupaten dan Kotamengalami angka penularan yang cukup signifikan.(Banjarmasin Post, 2021) Kabupaten Banjar merupakan salah satunya. Tercatat per 27 Mei 2021, ada 2.764 kasus positif dengan 91 jiwa meninggal
dunia.(Satgas Covid-19 Kab. Banjar, 2021)Tingginya angka ini membuat berbagai kegiatan belum kembali normal seperti sebelum masa pandemi. Contohnya adalah kegiatan belajar mengajar di sekolah dan perguruan tinggi yang masih dilakukan secara daring(Banjarmasin Post, 2021).

\section{METODOLOGI PENELITIAN}

Lokasi penelitian adalah di lingkungan Kampus IAI Darussalam Martapura sekitarnya. Penelitian dilaksanakan dengan membagikan angket kuesioner kepada para pelaku UMKM bersamaan dengan kegiatan Pengabdian Kepada Masyarakat Sosialisasi Transaksi Non-Tunai yang dilaksanakan oleh beberapa orang dosen FEBI bersama dengan mahasiswa.

Responden untuk penelitian ini berjumlah sebanyak 35 orang, sesuai jumlah pelaku UMKM yang terlibat dalam kegiatan Pengabdian Kepada Masyarakat tersebut. Skala pengukuran yang digunakan dalam angket ini adalah skala Guttman, yaitu skala pengukuran yang ada dua interval saja, memberikan jawaban secara tegas dengan opsi "ya atau tidak", "positif atau negatif", "pernah atau tidak pernah", "setuju atau tidak setuju", dan opsi lainnya. Hasil dari angket tersebut kemudian dideskripsikan dengan membandingkan dua interval tadi.

Tim juga melakukan penelitian melalui observasi, evaluasi dan kepustakaan, yaitu dengan cara mengumpulkan data dari buku-buku, literatur, dokumen, jurnal ilmiah, dan berbagai sumber lain yang berhubungan dengan penelitian ini.

\section{HASIL DAN PEMBAHASAN} Adaptasi Kebiasaan Baru

Kriteria Adaptasi Kebiasaan Baru di masa pandemi Covid-19 : 
1. Mencuci tangan dengan sabun dan air mengalir atau memakai hand sanitizer.

2. Memakai masker apabilakeluarrumah.

3. Menjaga jarak dan menghindari kerumunan.

4. Mengurangi mobilitas dan mengikuti program vaksinasi.(Kemenkes RI, 2020)

Tabel 1. Respon terhadap pernyataan selalu mencuci tangan dengan sabun dan air mengalir.

\begin{tabular}{|c|c|}
\hline Setuju & Kurang setuju \\
\hline 33 & 2 \\
\hline $94 \%$ & $6 \%$ \\
\hline
\end{tabular}

Berdasarkan tabel di atas, dapat diketahui bahwa sebanyak 2 orang responden mengaku tidak selalu mencuci tangan dengan sabun dan air mengalir, 33 orang mengaku selalu mencuci tangan dengan sabun dan air mengalir .

Tabel 2. Respon terhadap pernyataan selalu membersihkan tempat dan peralatan berjualan secara berkala dengan sabun atau disinfektan

\begin{tabular}{|c|c|}
\hline Selalu membersihkan & Tidak selalu \\
\hline 9 & 26 \\
\hline $26 \%$ & $74 \%$ \\
\hline
\end{tabular}

Berdasarkan tabel di atas, dapat diketahui bahwa sebanyak 9 orang responden mengaku selalu membersihkan tempat berjualan secara berkala, 26 orang mengaku tidak selalu membersihkan tempat berjualan.

Tabel 3. Respon terhadap pernyataan menyediakan tempat cuci tangan atau hand sanitizer ditempat berjualan

\begin{tabular}{|c|c|}
\hline Menyediakan & Tidak menyediakan \\
\hline 12 & 23 \\
\hline $35 \%$ & $65 \%$ \\
\hline
\end{tabular}

Berdasarkan tabel di atas, dapat diketahui bahwa sebanyak 12 orang responden mengaku selalu menyediakan tempat cuci tangan atau hand sanitizer, 23 orang mengaku tidak menyediakan.
Tabel 4. Respon terhadap pernyataan selalu mencuci semua peralatan dengan sabun setiap selesai berjualan.

\begin{tabular}{|c|c|}
\hline Selalu mencuci peralatan & Tidak selalu \\
\hline 3 & 32 \\
\hline $9 \%$ & $91 \%$ \\
\hline
\end{tabular}

Berdasarkan tabel di atas, dapat

diketahui bahwa sebanyak 32 orang responden mengaku tidak selalu mencuciperlatan dengan sabun setiap selesai berjualan. 3 orang mengaku selalu mencuci peralatan setiap selesai berjualan..

Tabel 5. Respon terhadap pernyataan selalu memakai masker setiap beraktivitas diluar rumah.

\begin{tabular}{|l|l|}
\hline Selalu memakai masker & Tidak selalu \\
\hline
\end{tabular}

\begin{tabular}{|c|c|}
\hline 21 & 14 \\
\hline $60 \%$ & $40 \%$ \\
\hline
\end{tabular}

Berdasarkan tabel di atas, dapat diketahui bahwa sebanyak 21 orang responden mengaku selalu memakai masker setiap beraktivitas diluar rumah, 14 orang mengaku tidak selalu memakai masker.

Tabel 6. Respon terhadap pernyataan jika memakai masker dari bahan kain, maka langsung mencuci setiap selesai beraktivitas.

\begin{tabular}{|c|c|}
\hline Selalu langsung mencuci & Tidak selalu \\
\hline 23 & 12 \\
\hline $66 \%$ & $34 \%$ \\
\hline Berdasarkan tabel di atas, dapat
\end{tabular}

diketahui bahwa sebanyak 23 orang responden mengaku selalu langsung mencuci masker bahan kain masker setiap selesai beraktivitas diluar rumah, 12 orang mengaku tidak langsung mencuci.

Tabel 8. Respon terhadap pernyataan kesadaran memakai masker karena memang mengetahui pentingnya bukan karena takut dirazia petugas.

\begin{tabular}{|c|c|}
\hline Karena kesadaran & Takut dirazia petugas \\
\hline 20 & 15 \\
\hline $57 \%$ & $43 \%$ \\
\hline
\end{tabular}


Berdasarkan tabel di atas, dapat diketahui bahwa sebanyak 20 orang responden mengaku selalu memakai masker karena memang atas kesadaran sendiri, 15 orang mengaku karena takut kena razia petugas.

Tabel 9. Respon terhadap pernyataan kesadaran untuk selalu menjaga jarak (Fisikal distansing) ketika melayani konsumen

\begin{tabular}{|l|l|}
\hline Selalu menjaga jarak & Tidak bisa menjarak \\
\hline
\end{tabular}

\begin{tabular}{|c|c|}
\hline 12 & 23 \\
\hline $34 \%$ & $64 \%$ \\
\hline Berdasarkan tabel di atas, dapat
\end{tabular}
diketahui bahwa sebanyak 12 orang responden mengaku selalu menjaga jarak aman ketika melayani konsumen, 23 orang mengaku tidak bisa melakukan / menjaga jarak dengan konsumen karena berbagai alasan, terutama ketika konsumen datang berbarengan.

Tabel 10. Respon terhadap pernyataan kesadaran untuk tidak berkerumun dengan orang banyak.

\begin{tabular}{|c|c|}
\hline $\begin{array}{c}\text { Berusaha untuk } \\
\text { tidak berkerumun }\end{array}$ & $\begin{array}{c}\text { Tidak takut untuk } \\
\text { berkerumun }\end{array}$ \\
\hline 9 & 26 \\
\hline $26 \%$ & $74 \%$ \\
\hline
\end{tabular}

Berdasarkan tabel di atas, dapat diketahui bahwa sebanyak 9orang responden mengaku selalu berusaha tidak berkerumun , 26 orang mengaku tidak takut untuk berkerumun dengan orang banyak.

Tabel 11. Respon terhadap pernyataan mengatur kursi yang sudah berjarak untuk konsumen.

\begin{tabular}{|c|c|}
\hline $\begin{array}{c}\text { Mengatur kursi yang sudah } \\
\text { berjarak untuk konsumen }\end{array}$ & $\begin{array}{c}\text { Tidak } \\
\text { mengatur }\end{array}$ \\
\hline 7 & 28 \\
\hline $20 \%$ & $80 \%$ \\
\hline
\end{tabular}

Berdasarkan tabel di atas, dapat diketahui bahwa sebanyak 7 orang responden mengaku mengatur kursi yang sudah berjarak,
28 orang mengaku tidak mengatur kursi untuk konsumen.

Tabel 12. Respon terhadap pernyataan keluar rumah hanya untuk bekerja atau karena alasan yang sangat penting atau mendesak.

\begin{tabular}{|c|c|}
\hline $\begin{array}{c}\text { Keluar rumah hanya } \\
\text { untuk alasn yang } \\
\text { penting atau mendesak }\end{array}$ & $\begin{array}{c}\text { Tidak membatasi } \\
\text { bepergian keluar } \\
\text { rumah }\end{array}$ \\
\hline 16 & 19 \\
\hline $46 \%$ & $54 \%$ \\
\hline
\end{tabular}

Berdasarkan tabel di atas, dapat diketahui bahwa sebanyak 16 orang responden mengaku keluar rumah hanya untuk alasan yang penting dan mendesak , 19 orang mengaku tidak membatasi bepergian keluar rumah.

Tabel 13. Respon terhadap pernyataan pemahaman tentang proses penularan dan risikokematian akibat Covid-19.

\begin{tabular}{|c|c|}
\hline $\begin{array}{c}\text { Mengetahui dan memahami } \\
\text { proses penularan dan risiko } \\
\text { kematian akibat Covid }\end{array}$ & $\begin{array}{c}\text { Tidak } \\
\text { mengetahui }\end{array}$ \\
\hline 13 & 22 \\
\hline $37 \%$ & $63 \%$ \\
\hline
\end{tabular}

Berdasarkan tabel di atas, dapat diketahui bahwa sebanyak 13 orang responden mengaku mengatahui dan memahami, 22 orang mengaku tidak terlalu memahami.

Tabel 14. Respon terhadap pernyataan upaya pemerintah menyediakan Vaksin untuk mencegah penularan Covid-19.

\begin{tabular}{|c|c|}
\hline $\begin{array}{c}\text { Mengetahui dan } \\
\text { bersedia untuk } \\
\text { divaksinasi }\end{array}$ & $\begin{array}{c}\text { Tidak bersedia untuk } \\
\text { divaksinasi }\end{array}$ \\
\hline 19 & \multicolumn{2}{|c|}{16} \\
\hline $54 \%$ & $46 \%$ \\
\hline Berdasarkan tabel di atas, dapat \\
diketahui bahwa sebanyak 19 orang \\
responden mengaku mengetahui dan bersedia \\
untuk di vaksinasi, 16 orang mengaku tidak \\
bersedia untuk divaksinasi.
\end{tabular}


Tabel 15. Respon terhadap pernyataan upaya pemerintah mensosialisasikan vaksin dengan mengeluarkn Fatwa MUI tentang halalnya vaksin

\begin{tabular}{|c|c|}
\hline $\begin{array}{c}\text { Mengetahui bahwa } \\
\text { vaksin halal }\end{array}$ & Masih ragu-ragu \\
\hline 32 & 3 \\
\hline $91 \%$ & $9 \%$ \\
\hline
\end{tabular}

Berdasarkan tabel di atas, dapat diketahui bahwa sebanyak 32 orang responden mengaku sudah mengatahui bahwa vaksin sudah halal MUI , 3 orang mengaku masih ragu-ragu.

\section{KESIMPULAN}

Kesimpulan yang dapat diambil dari hasil analisis yang telah dilakukan adalah bahwa sebagian pelaku UMKM disekitar lingkungan kampus IAI Darussalam Martapura masuk dalam kategori mematuhi kebijakan adaptasi kebiasaan baru yang diterapkan oleh pemerintah. Hal ini dikarenakan sebagian besar dari mereka mengaku memang memahami akan bahaya dari penularan Covid-19.Hal tersebut dibuktikan dengan kesadaran dengan selalu mencuci tangan menggunakan sabun dan air mengalir dan memakai masker setiap beraktivitas diluar rumah. Namun, sebagian lainnya mengaku tidak dapat menjaga jarak dan menghindari kerumunan, tidak dapat mengurangi mobilitas dikarenakan berbagai alasan, terutama karena alasan ekonomi. Sebagian dari responden mengaku sudah mengetahui dan bersdia untuk mendapat vaksinasi.

Penulis berharap akan ada keberlanjutan dari penelitian ini, dengan tujuan untuk mengetahui apakah ada perubahan perilaku dan kesidiplinan terhadap kebiajakan adaptasi kebiasaan baru serta untuk mengetahui dampak yang diakibatkan dari ketidak disiplinan tersebut.

\section{DAFTAR PUSTAKA}

Abdul Wahab, S. (1997). Analisis Kebijakan .

Al-Gonary, S. M. (2021). Covid-19 pandemic and religion :Islamic law perspective. Global Journal of Public Health Medicine, 3(1), 321.

Arikunto, S. (2010). Prosedur Penelitian: Suatu Pendekatan Praktis. Jakarta: Kencana.

Banjarmasin Post. (2021, Maret 1). 253 Sekolah di Banjar Usulkan Pembelajaran Tatap Muka, PTM Tunggu Edaran Disdik Kalsel. Retrieved Mei 27, 2021, from Banjarmasin Post: https://banjarmasin.tribunnews.com/2 021/03/01/253-sekolah-di-banjarusulkan-pembelajaran-tatap-mukaptm-tunggu-edaran-disdik-kalsel.

Banjarmasin Post. (2021, Mei 12). Ini sebaran Covid 19 di Kabupaten Banjar Kalsel. Retrieved Mei 27, 2021, from Banjarmasin Post: https://banjarmasin.tribunnews.com/2 021/05/12/ini-sebaran-kasus-covid-19di-kabupaten-banjar-kalsel

Effendi, M., Masriyah, M., \& Riadi, S. (2020). Islamic contribution in the covid-19 pandemic: viewed from history. Abjadia : International Journal of Education, 05(02), 157-165.

Handoko, T. H. (2016). Manajemen (2 ed.). Yogyakarta: BPFE.

Kemenkes RI. (2020). Pedoman Pencegahan dan Pengendalian Corona Virus Disease (COVID-19) Revisi ke-5. Jakarta: Kementerian Kesehatan Republik Indonesia.

Kemenkeu RI. (2021, Februari 23). Pemerintah Jaga Sentimen Positif Pemulihan Ekonomi. Retrieved June 14, 2021, from Siaran Pers Kementerian Keuangan Republik Indonesia SP - 08 /KLI/2021: www.kemenkeu.go.id\%2Fmedia\%2F1 
7237\%2Fsp08-pemerintah-jagasentimen-positif-pemulihan-ekonomiperkuat-implemen

Kemenkop UKM RI. (2018). PERKEMBANGAN DATA USAHA MIKRO, KECIL, MENENGAH (UMKM) DAN USAHA BESAR (UB) TAHUN 2018-2019. Retrieved Mei 27, 2021, from Kementerian Koperasi dan UKM RI: https://kemenkopukm.go.id/dataumkm/?8dg4W1H50GB2JOlUyA7Z3 L6U5gu6zwCxQismJziA5j3ExeZlfX

KemenkopUKM RI. (2020, Oktober 9). Sektor UMKM Menjadi Kunci Pemulihan Ekonomi di Tengah Pandemi. Retrieved Juni 14, 2021, from Kementerian Koperasi dan UKM RI:https://kemenkopukm.go.id/read/se ktor-umkm-jadi-kunci-pemulihanekonomi-di-tengah-pandemi

Poerwadarminta, W. (1985). Kamus Besar Bahasa Indonesia. Jakarta: Balai Pustaka.

Satgas Covid-19 Kab. Banjar. (2021, Mei 27). Banjar Tanggap Covid-19. Retrieved Mei 27, 2021, from Data Penyebaraan Covid-19 di Kab. Banjar: https://layanan.banjarkab.go.id/corona virus/

Satgas Penanganan Covid-19 Nasional RI. (2020, Mei 6). 5 Skema Perlindungan dan Pemulihan UMKM di Tengah Pandemi COVID-19. Retrieved Juni 14, 2021, from Materi Edukasi Masyarakat Umum: https://covid19.go.id/edukasi/masyara kat-umum/5-skema-perlindungan-danpemulihan-umkm-di-tengah-pandemicovid-19

Satgas Penanganan Covid-19 Nasional RI. (2021, Mei 27). Data Sebaran Covid19. Retrieved Mei 27, 2021, from Satgas Penangangan Covid-19 Nasional: https://covid19.go.id/
Setiawan, G. (2004). Implementasi dalam Birokrasi Pembangunan. Jakarta: Balai Pustaka.

Tachjan, T. (2008). Implementasi Kebijakan Publik. Bandung: Bumi Aksara.

Tambunan, T. (2021). MSMEs in Times of Crisis: Evidence from Indonesia. JDE (Journal of Developing Economies), 05(02), 91-106.

Tim Pakar Gugus Tugas Covid-19. (2020, Juni 24). Materi Edukasi Adaptasi Kebiasaan Baru Menuju Masyarakat Produktif dan Aman COVID-19. Retrieved Mei 27, 2021, from Satuan Tugas Penanganan COVID-19: https://covid19.go.id/edukasi/masyara kat-umum/adaptasi-kebiasaan-barumenuju-masyarakat-produktif-danaman-covid-19

WHO. (2020, December 1). Mask use in the context of COVID-19: Internal Guidance. Retrieved Mei 27, 2021, from World Health Organization: https://www.who.int/publications/i/ite $\mathrm{m} /$ advice-on-the-use-of-masks-in-thecommunity-during-home-care-and-inhealthcare-settings-in-the-context-ofthe-novel-coronavirus-(2019-ncov)outbreak 